great extent be formed as to the probability of return of the disease in other glands, or the increase or subsidence of small deep glands that may have been left by the condition and progress of the scar. Ugly scars may be removed and the patient's appearance greatly improved, but the cause must at the same time be taken away or the result will be disappointing. The question of early or late removal is a very important one, and can only be answered by the consideration of the special features of each particular case. As a rule, there are decided advantages attending early removal. In the early stages the glands are as a rule more movable and more easily taken away; there is also to be borne in mind, as indicating early removal, the important fact that an infected gland constantly tends to infect others, and is a source of danger so long as it remains; glands too, if left, will often break down, capsule giving way, and discharge, not externally through the skin, but into the cellular tissue of the neck, causing burrowing sinuses and extension generally of the disease. On the other hand, removal whilst the disease is in an early and progressive stage is more likely to be followed by a return than is removal when the disease is in an arrested and quiescent condition. And, coteris paribus, the younger the child the more likely is the disease to recur. No general rule can be given, but each case must be taken on its merits. If the constitutional disturbance set up by the glands is sufficient to maintain increase of temperature, it is better to operate. Of course, the constitutional condition and the local trouble act and react on each other, but generally an indication for action or delay can be got at by deciding as to whether it is chiefly the constitutional condition which, in addition to perhaps local causes, is developing and maintaining the gland trouble; or whether this gland disease, having been started by combined local and constitutional causes, is now in itself injuriously affecting and deteriorating the health. In many of my patients the latter has undoubtedly been the case, and I have numerous charts showing the temperature, which has ranged from $100^{\circ}$ to $103^{\circ} \mathrm{F}$., dropping to normal shortly after removal, with a corresponding improvement in the general health. But in many cases there are distinct benefits to be obtained by waiting. The glands will not altogether return to their normal condition and size, but they may become smaller, surrounding inflammatory deposits may be absorbed, adhesions may be set free, loosened, or stretched, general health may be improved, and a more favourable state of the patient, both locally and generally, be brought about. The social position of the patient must also influence our action. In the case of a poor child, residence at the seaside, except for a limited period in a hospital, is unattainable, and time is of importance. The well-to-do classes, on the other hand, are averse to submit to operation until less decisive measures have been first tried. Finally, I would say wait, if possible, to establish general health and get disease quiet.

I cannot help thinking that excision of scrofulous glands is an operation which rests on sound surgical principles. We have a diseased, an irreparably diseased, condition in organs which the body can well spare-a condition which tends constantly to cause infection by continuity of adjoining glands, and even by means of the blood, to develop tnberculous disease in distant parts. Why should this diseased product be allowed to remain to work its own sweet will unmolested and undisturbed? Tuberculous disease is removed from all other accessible parts or organs; why should glands be privileged? I submit there is every reason why they should be removed, and removed thoroughly. Take the case of a family of scrofulous tendencies. One member only may actually develop the disease, say, in the form of scrofulous glands ; if this child's diseased glands are thoroughly removed, if all sources of irritation are removed and the child's health established by being sent to the seaside, that child is put back in the position of his brothers and sisters who have never had the disease. He is not more likely to have a return of the scrofulous glands than his brothers and sisters are to develop them-in fact, he is cured. The only valid argument that could be used against the excision of scrofulous glands is the possibility of undue risk. Scrofulous glands are situated usually in the midst of important vessels and structures, and their removal might be considered dangerous. I can only state that I have excised scrofulous glands for many years, and that I have never lost a case. I attribute this success partly to good fortune, but mainly to the fact that I never incur, by premature closing of the wound, the slightest risk of retention of discharges or bagging. I have operated on many cases of great enlargement. I have removed more than a pound's weight in glands from one patient, and more than one hundred in number from another. I have excised glands in a case where the mass was sufficiently large to threaten suffocation. My colleagues are doing the same, and we can prove, by a great number of cases, that the operation is not attended with undue risk, and that the results are good.

Margate.

\section{AROSA AS AN ALPINE HEALTH RESORT. ${ }^{1}$}

BY WM. EWART, M.D., F.R.C.P.,

pHysictan to st. GEorgile's hospital and to the belgrave hosPITAL FOR CHILDREN ; LATE ASSISTANT PHYSICIAN AND

PATHOLOGIST TO THE BROMPTON HOSPITAL FOR CONSUMPTION AND DISEASES OF THE CHEST.

AfTER five successive winter visits to the Alps, I am more than ever of opinion that time is working in favour of the Alpine treatment of phthisis. The natural repugnance of most patients to the idea of a glacial winter, and a wise diffidence on the part of the profession, have checked for a long time its wider application; but the delay has been of use as a means of testing its value and of confirming its ultimate success. We now more fully realise that, if phthisis is to be cured by residence in the Alps, the fleeting opportunity must be seized early; this circumstance alone has led, during the past few years, to a progressive increase in the size of the winter colony. Moreover, in addition to consumptives, many have found their way to the Alps in whom pulmonary disease was merely threatened. And, lastly, the remarkable results obtained in the treatment of early phthisis have awakened most physicians to the capabilities of the Alpine cure in a larger class of cases presenting in common the feature of depressed vitality. Nevertheless, for a considerable number of patients the length and the hardships of the journey to the high Alps have hitherto been an insuperable objection. The winter journey to the Engadine is likely for some years to retain its romantic and adventurous features. But to Davos a railway is already partly laid; this winter it will have reached Klosters, leaving but ninety minutes instead of seven weary hours of diligence journey; and in the following autumn Davos will possess its own terminus, and will doubtless welcome a vastly increased number of visitors, both invalid and healthy. From that day the charm of an Alpine winter holiday will cease to be the secret of the few; and it may safely be predicted that Davos will become the great centre in the High Alps, not for patients only, but for lovers of mountain climbing, of skating, and of the toboggan. On the other hand, instead of being as heretofore an Ultima Thule, Davos will henceforth provide ready access to other favoured spots, and residence in the altitudes will admit of greater variety than in the past. Foremost among the members of the Davos group of health resorts must be mentioned Wiesen and Arosa, each differing from the other and from Davos in its climatic virtues, and each excelling in its own special variety. Wiesen has already for several years subsisted as a satellite of Davos, but although it has been brought to notice by the writings of Dr. Tucker Wise, it has not yet achieved the development for which its beautiful climate, and its yet more beantiful scenery, afford secure pledges. Arosa, though later in the field, is likely to equal the fame of its predecessors. Hitherto, but for a paper by Dr. Fritz Egger in the Correspondenz Blatt fur Schweizer Aerzte for 1886, it is unknown to medical literature. The brief account which follows may therefore present some interest, especially since, through the kindness of Dr. Egger and of Dr. Herwig (the former practising and the latter residing in Arosa), I am able to supplement my own observations with some of the local knowledge acquired by old residents.

Upwards of 400 years ago a handful of adventurous Davoser shepherds crossed the mountains which form the western boundary of the valley of Davos, and founded in the smaller and more elevated neighbouring valley a village, to which they gave the name of Erosen. The new

1 Written at Arosa in February, and communicated in March of the present year. 
settlement remained for a long period within the jurisdic- tinuous chain separates the Prättigau and the Davos Valley tion of Davos; and to the present day a vestige of the from the district of Arosa. Between the latter and Wiesen former allegiance survives in connexion with the administration of relief to the poor. The colony never acquired any great size; but with the ill-advised sale to the city of Chur of the richest of its woods and of its grazing-alps, it entered upon a long period of decline. Two years ago its permanent population had dwindled to fifty. But Arosa was destined to be colonised once more from Davos, not as formerly with sturdy mountaineers attracted by the fragrance of its pastures, but with patients anxious for a winter shelter under its snow-clad mountains. The fresh immigration was headed, six years ago, by Dr. Herwig, and two years later by Dr. Egger. During the winter 1887-8, in scattered array, a total of eleven visitors were content to put up with primitive accommodation. But, with the onset of the next winter, Arosa, long treasured by the Swiss as a delightful summer refuge, almost untrodden by the foreign tourist, long foretold by experts as the winter station of the future, suddenly sprang into existence as an intervene the Sandhübel Mountain, the gorge of the Welschtobel and the ridge of the Schafsrücken. The higher or southern part of the valley is included between this ridge and the Weisshorn ; whilst into the northern half opens the Welschtobel. The valley is parallel with the valley of Davos and slopes from S.W. to N.E. Its shape would be a perfect oval but for the protrusion, half-way across it, of a small semicircular mountain, the Tschuggen, which renders it roughly kidney-shaped, and divides it into a northern and a southern half. The latter contains, in descending tiers, the elevated Aelpli-see; the Schwelli-see, also of considerable altitude; and the hamlet of Arosa. This is, strictly speaking, the Arosa Valley as opposed to the See-grube on the other side of the Tschuggen. The complete absence of trees and the huge snow-slopes into which it gradually rises impart in winter to this end of the valley a wild arctic aspect.

The sanatorium is built half-way down the southward

\section{MAP OF AROSA,}

WITH AN INDICATION OF ITS RELATIONS TO THE DAVOS GROUP.

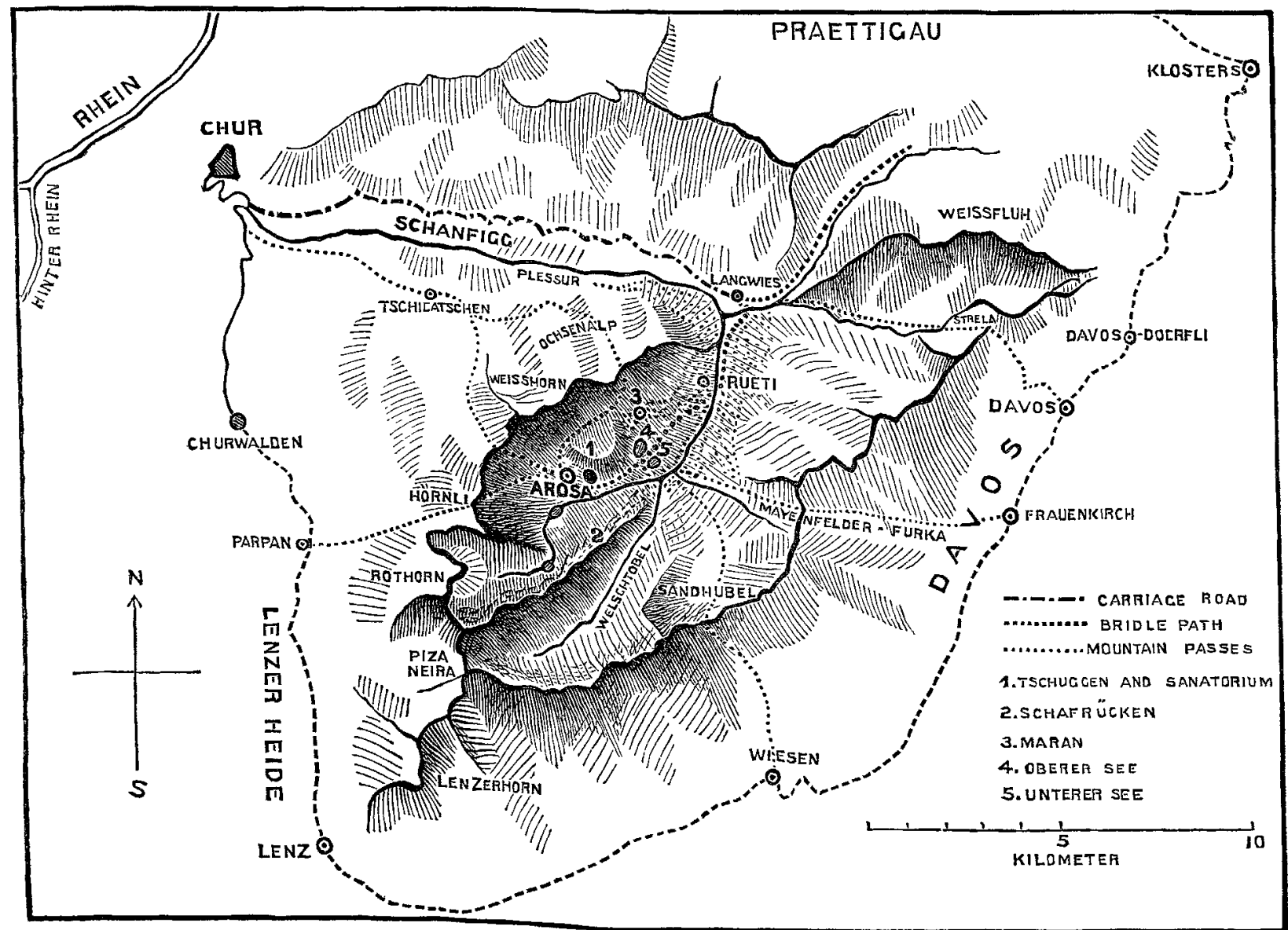

N.B. The scale of measurement is applicable only to the Valley of Arosa, not to the surroundings, which are merely indicated, without reference to distance.

Alpine health resort. The sanatorium, built by Dr. Herwig during the spring and summer of 1888 for the accommodation of thirty patients, was invaded, even before its completion, by visitors unable to find room in any of the six summer hotels; and during its first winter it has been occupied by twenty-four residents. The patients, mostly German, but including two English ladies, a Belgian, and, strange to say, a Frenchman, have enjoyed the undivided run of this lovely valley, free to toboggan down its long slopes, free to roam on snow-shoes, fearless of the landjäger, over its hills, meadows and hurdles, and to exchange distant jodels through stillness yet undisturbed by any strange voices; but at times the saddening thought has occurred to them that the same monupoly of privileges will never be theirs again.

The natural advantages of the valley of Arosa are probably unsurpassed. An oblong amphitheatre of mountains surrounds the valley on all sides, except at the north-east corner where the Plessur stream escapes with a sharp bend, between densely wooded hills, into the Schanfigg Thal. This break in the investing heights is guarded by the Weissfluhe; and from this mountain to the Piza Neira a con- slope of the Tschuggen, at an elevation of about $6200 \mathrm{ft}$. near the upper limit of the pine-tree woods, which extend from this point northwards as far as the end of the valley, clothing its bottom and its opposite slopes, and leaving in the See-grube an open surface of tolerably level ground around the two lakes, known as the Unter-see and the Ober-see. The sanatorium, absolutely sheltered from the north wind, is open to the Föhn, which seldom blows, and is taken in flank by the milder touch of the Heiterluft (fine weather air) or west valley wind, which descends every day, across Arosa, from the Hörnli. It faces due south, and receives, in addition to the direct sun rays, much reflected heat from the snow-clad Schafsrücken; it also enjoys a fine view over the picturesque snow-tipped woodland scenery to the north, which contrasts pleasantly with the desolate landscape to the south. From the narrow gully contained between the foot of the Tschuggen and that of the Schafsricken the valley broadens out northwards into the See-grube, which has a mean elevation of 5800 feet. Here the protection from wind, although not absolute, is as good as need be desired, and I am told by winter residents that during the heavy Föhn-storms the woods afforded a perfectly 
still retreat. On the shores of the Ober-see and of the Unter-see I noticed lovely sites, two of which are already reserved for large buildings. Hitherto valley mists, so common in the still valleys, are almost unknown, even in the See-grube.

Arosa offers ample opportunities for out-door exercise. A long level walk extends through the woods to Maran; the other walks are more or less steep, and their choice is limited in winter. Fortunately snow-shoes, almost unknown at Davos and St. Moritz, are here in constant use and have rendered the patients independent of the few bridle-paths with which the natives are satisfied. With their help some of the stronger invalids have ascended the Weisshorn, and even the Rothhorn, and have visited most of the passes. The hill sides are singularly well adapted for the use of the toboggan, and some excellent skating was enjoyed on the lower lakes before the heavy snow-falls. Meanwhile, patients unfit for exercise recline in the sun under rugs or eider-down pillows on the balconies or in the verandal.

The meteorological observations which have hitherto been collected entirely confirm the inference that Arosa is typically a serene altitude. Absolute stillness, which is not an unmixed boon, does not exist here. The Heiterluft provides daily for a sufficient renewal of air, and the See-grube possesses an additional air-current passing from the valley of Langwies to the Welschtobel. As to the quality of the air, after a circular journey from Davos to the Engadine, and from the Engadine to Arosa, I found here rather more stimulation than at Davos, and decidedly less stimulation than in the Engadine. As far as I was able to compare notes, the oscillations of the weather were practically the same here during the month of February as at Davos. Although a thousand feet higher than Davos, Arosa possesses a milder temperature. The following fact requires no comment: mid-day dinner was served to the patients in the open verandah seven times in December last, eleven times in January, and twice in February. According to observations made by $\mathrm{Mr}$. P. Haenel, and kindly placed by him at my disposal, the interval between sunrise and sunset reached in December last a minimum of five hours and fifty-three minutes and a maximum of six hours and twenty minutes; for January the maximum was seven hours, and for February eight hours.

The following are the averages of the temperatures registered in the shade from Feb. 3rd to the 14th inclusive. Average at 7 A.M.: - $11.7^{\circ}$ centigrade; at 1 P.M.: $-7 \cdot 7^{\circ}$; at 9 P.M. : - $10 \cdot 3^{\circ}$. An ordinary thermometer, suspended in contact with a wooden beam, on the sunny side of the sanatorium, registered the following values during the same series of twelve days, at 12 noon:

$$
+12 \cdot 5^{\circ} ;-2^{\circ} ;-3 \cdot 5^{\circ} ;-2^{\circ} ;+22^{\circ} ;+31 \cdot 5^{\circ} ;-1 \cdot 5^{\circ} ;
$$$$
+2 \cdot 7^{\circ} ;-2^{\circ} ;+1 \cdot 5^{\circ} ;+20^{\circ} ;+3.5^{\circ} \text { centigrade. }
$$

The wide variations noticed in the series are evidence of the unsettled state of the atmosphere during the period in question, widely contrasting with the steady fine weather which prevailed throughout November, December, and January in Davos and in Arosa. The highest temperature registered by the same instrument in December was $+34 \cdot 5^{\circ}$ centigrade. The lowest temperature registered in the shade (at 7 A.M. and at 9 P.M.) was $-20^{\circ}$ centigrade. Although these various observations were not made with protected thermometers, they afford a rough idea of the variations in temperature to which are exposed winter residents in the altitudes, and which the dryness of the air enables them to tolerate without discomfort.

In conclusion, Arosa, the latest addition to the list of Alpine resorts, bids fair to be one of the best; and we may well wonder that so eligible a spot should have been hitherto overlooked. The mountains by which it is so remarkably sheltered have placed it beyond the reach of most invalids. To the present day, Arosa possesses the charm of being accessible only to foot passengers; in winter, by a single path, from Langwies, a stiff walk of from two hours and a half to three hours; but in summer by six mountain passes in addition. A carriage road is, however, in course of construction, and before next winter it will be possible to cover the whole distance from Chur in four hours and a half. Perhaps also before then ample accommodation will have been prepared for a larger winter colony. As regards the sanatorium, the success already achieved among a German clientele, under the able management of Frl. Herwig, renders it more than doubtful whether any room will be left next winter under its roof for the reception of English visitors. But if any should make the attempt to partake of its hospitality, they should come prepared to find themselves in the minority.

Curzon-street, $\mathrm{W}$.

\section{AN ESSAY ON THE \\ FUNCTIONS OF INDIFFERENT CELIS IN THE HUMAN ORGANISM.}

BY JAMES DICKINSON.

(Concluded from page 636.)

THE normal occurrence of the migration of leucocytes must be considered as established. What do they do when they have migrated? Is there in the body any small but constant deposit of cell débris (such as results copiously from an injury) demanding bodily removal, and providing just such a task as the wandering cells in the tissues are competent to perform? It seems extremely likely that there is this deposit. The life of a cell is not in point of duration that of the organism of which it is but a tiny item. It is believed that each cell lives its little life and dies while the complex organism continues its existence. The analogy of all communities tells us that this must be so, and that it is so is recognised by authorities. "We know that an epithelium cell, as notably in the case of the skin, may be bodily cast off and its place filled by a new cell, and probably a similar disappearance and renewal of histological units take place in all tissues of the body to a variable extent." (Foster.) Again: "The tissues and organs of the animal body in the exercise of their functions are subject to loss of material which is restored by nutrition." (Quain's Anatomy.) Every surface yields us abundant material evidence that this proposition is true, and we need not hesitate to accept it. Let us, then, ask the question, What becomes of the dead cell-forms? It would require but a very minute percentage of deaths per diem to scatter some thousands of dead cells about the body daily. Such as die at the surface are free to return straightway to the dust whence they sprang. But the bulk of cells are cut off from this easy mode of disposal. What becomes of them? The authority last quoted says: "In the vascular tissues the old or effete matter must be first reduced to a liquid state, then find its way into the bloodvessels or lymphatics along with the residual part of the nutritive plasma and be by them carried off." No doubt this statement partially disposes of the difficulty, but it takes too much for granted to be accepted without challenge. Leaving out of count the products discharged by ka tabolism while it main tains the limits consistent with the life of the protoplasmic molecule, the expression "old or effete matter" includes the products left when protoplasm undergoes death and dissolution - products which, as we have seen, must be constantly deposited in the tissue. Now, in the statement just quoted all these products are assumed to be soluble in the lymph stream. But one of the products freed by the natural dissolution of protoplasm is fat, as is seen when a mass of protoplasm cut off from its blood-supply undergoes fatty degeneration. What happens is broadly this. The complex molecule of protoplasm, in the absence of material wherewith to carry on its constructive changes, continues its destructive changes uncompensated till it is fairly broken up into less complicated but more stable molecules, some of which are fatty. We see the same thing in the tissue degenerations of old age, when the machine is nearly run down and destructive metabolism generally is gaining the upper hand of constructive. It is by so carrying its destructive metabolism too far that one conceives all protoplasm ultimately dies, if left to die in the course of nature, a point being at last reached at which no reconstruction is possible and the molecule breaks up into stable residues. It is most probable that all forms of the protoplastic molecule contain, in addition to a proteid basis, fatty and carbohydrate residues. The combination may be in different proportions in different forms, but probably all forms on undergoing natural dissolution yield residues representing these three classes of substances. At all events the facts show that a fatty residue is almost invariably a product of 